The Sustainable City XIII 555

\title{
ARCHITECTURAL PROGRAMMING FOR BALANCED LOCAL URBAN CENTERS
}

\author{
ROBERT K. BARELKOWSKI* \\ West-Pomeranian University of Technology in Szczecin, Poland
}

\begin{abstract}
Both architectural and urban design are deeply rooted in programming or construing programmatic frameworks which are then transposed into physical structures. This programmatic aspect contributes to the nature of the city, but quite often is either masked under multiple layers of architectural or urban design related manifestations or is blurred due to extensively complicated structure. In the latter example, urban structure appears to be too developed to grasp the sophisticated role programming plays in building the balanced, sustainable city. There are, however, rare cases in which the program appears to determine the validity of the entire project because the structure is to become a local urban center. Its scale is sufficiently comprehensible, certainly not too big, and at the same time autonomous enough that it is possible to expose the significance of urban program and its compilation as a separate, important step within the process of urban design. The paper focuses on case studies - two autonomous estates, one of which is central for the community, the other one is peripheral. Both cases display the approach to programming using similar methods in order to distinguish similarities and differences affecting the strategy, the approach to a particular task, and the tailoring of the design process in this early stage. This work will present selected sustainability attributes, namely availability, accessibility, and connectivity, as drivers for programming balanced functions and balanced areas.

Keywords: sustainable development, spatial planning, urban programming.
\end{abstract}

\section{INTRODUCTION}

Both architectural and urban design are deeply rooted in programming or construing programmatic frameworks which then are transposed into physical structures. This process allows to contain the immaterial within the physical, to accommodate metabolism of the city within the confines of artificially created environment, or within interiors of particular buildings the city is comprised of. This programmatic aspect contributes to the nature of the city, but quite often is either masked under multiple layers of architectural or urban design related manifestations or is blurred due to extensively complicated structure. In the latter example urban structure appears to be too developed to grasp the sophisticated role programming plays in building the balanced, sustainable city. There are, however, rare cases in which program appears to determine the validity of the entire project, because resultant structure is to become local urban center. Its scale is sufficiently comprehensible, certainly not too big, and at the same time autonomous enough, that it is possible to expose the significance of urban program and its compilation as a separate, important step within the process of urban design. Function, manifesting the purpose of the area, must absorb fluctuations in use of space, changes in profile of residents, their age and preferences. In this limited research some aspects of dynamic planning approach cannot be properly recognized due to extremely complex nature - multicultural traits intermingling in urban space, more sophisticated modelling of urban realities, multiplicity of social and cultural spaces existing in one physical space. Therefore, this functional approach must be seen as a contribution to broader, more significant shifts of planning and designing practice [1, pp. 628-629].

* ORCID: http://orcid.org/0000-0002-2375-4257 
This paper aims to illuminate the connection between the community and built environment, an indispensable link exposing the importance of time-space of the city within narrow scope of preliminary planning and design activity, in its limited form. Successful design effort means that future changes can be implemented or absorbed, that alterations in use, in social structure including age, sex, ethnicity and other characteristics, which partially refers to problem discussed by Graham and Healey, when they point out to the expected transformation of planning practice towards more profound understanding and implementation of time-space aspects, to tackle the limitations of two-dimensional, traditional representations and simplifications. This approach attempts to build a small block of multi-level, multi-scale model [2, pp. 764-765], which may be related to that presented by Spiekerman and Wegener [3, pp. 68-70].

The contemporary role of urban planning and design can be understood as setting conditions for the built environment to be made and thrive, to be able to sustain itself not only in physical terms, but also in social and cultural terms. The aspect of distinction, clear identity profile, as Madanipour writes, serves the purpose of social integration and at the same time becomes the source of economic strengths for the community [4, pp. 181-182]. It allows to build self-repairing and self-rebuilding chains of places connected with metabolic processes to which spatial identity is one of essential contents expressed by selected strategy of development [5, pp. 671-672].

The research presented in this paper focuses on practically implemented mechanisms which are aimed at improving the results of urban design process by adding mechanisms that objectify the process of design. While some elements of urban design may be attributed to intangible aspects, its complex nature calls for more comprehensive, more reasoned and disciplined approach. In early stages of planning and design foundations for spatial potential are laid and refer to constraints as well as maximize aesthetic, social and functional gains for the urbanized space [6, p. 21].

\section{DEMOGRAPHY AS A FORCE BEHIND URBANIZATION}

Urban design focuses on reconfiguration of the environment. Either rural, open landscape, or urban setting becomes the subject of transformation initiated to deliver particular result initiated due to social needs, expectations or plans - whether represented by local authorities, individuals or business enterprises. On the one hand there are the forces of market, on the other hand there are requirements to be fulfilled in order to maintain the quality of life.

Within agglomerations, there are numerous examples of mismanaged programming: dense estates without public space, lacking recreation facilities, complex multi-use estates combining apartments and services, but devoid of kindergarten, school, church or healthcare facilities. These latter deficit public services are often excluded from urban design due to economic calculation of private parties and their lack of interest to invest into these facilities. Monofunctional or economy-driven development, particularly in larger estates, should never be taken as a priori solution. Instead, careful programming of the estate should reflect significant needs of local community in context of general requirements - specific number of inhabitants will require particular public services at their disposal, but local preferences will determine detailed proportions, shares, and hierarchy of these services. Spatial comfort, and the quality of life of residents, at least its material, spatial aspects that can be seen as the livability attribute, can be achieved when balanced and appropriately fitted urbanized environment is created and supplemented and connected to natural components of the environment. These important goals are direct manifestations of link between social and psychological sphere of human life and its environmental sphere. The balance allows to produce urbanized space on planning and urban design level allowing the architect to 
supplement the creation of positive environment with place-making or, to put it simply, architectural design [7, pp. 5-6].

The demography determines the spatial development and three sets of constraints are essential to grasp its impact on how the estate is supposed to function.

The first set of constraints is determined by profiling local community using demography, by current status of society depicted in numbers reflecting the composition of society, but also various tendencies, leading to the particular status. Number of youngsters, children, will affect programming directly, number of elderly persons will influence scale of required dedication to relevant solutions. Second set is directly appointed by the first one, while it is related to spatio-temporal nature of the environment. Neither society, nor its needs, nor the urban setting manifested as a result of both society and its aspirations, are constant. They often change, their complex nature altered partially, usually gradually, but a different rate within different aspects. Estates with once young inhabitants will inevitably grow and its population will become older (as average), built substance and infrastructure will become technically worn off, needs will evolve reflecting the tides of civilization, technological advancement, but also fashion, trends, current worldview, changing local identity. Social composition will absorb people from other communities, other nations, races, cultures, and in turn these new members will contribute to reshape the culture, behaviors, and expectations of the community. The third set of constraints is related to unpredictability, or to be more precise, to indeterministic nature of urbanized environment. The city as a system is never balanced, its subsystems altering their shape, adjusting to everchanging urban tissue. Once prominent districts become less attractive, others gain importance. Some areas prosper and acquire gradually more and more cultural significance, other deteriorate and become derelict. Generations of local community pass, and their connection to particular zones of the city changes, role people attribute certain places with also fluctuate.

\section{THE CONCEPT AND THE FRAMEWORK}

Urban programming can be understood as in-design early conceptualization of purposeful determination of goals for the urbanization process. Programming serves the purpose of defining the functional aspect of design, constituting the aims the development has to fulfill in order to positively respond to social needs. It is essential for a designer to understand their role, it affects the process and influences urban typologies, stipulated parameters, and spatial interrelations designer is going to propose, and ultimately, after optional and recommended participation of third parties, deliver.

The vehicle to compose spatial program for an urban estate is seen as a result of activities corresponding to the three sets of constraints. Its framework is shown in Table 1.

Table 1: The PRS framework for urban programming.

\begin{tabular}{|l|c|c|c|}
\hline & 1 & 2 & 3 \\
\hline Set of constraints & Demography & Time--space & Unpredictability \\
\hline $\begin{array}{l}\text { Programming (referential element } \\
\text { within PRS method) }\end{array}$ & $\begin{array}{c}\text { Community } \\
\text { profiling }\end{array}$ & $\begin{array}{c}\text { Tendencies } \\
\text { simulation }\end{array}$ & $\begin{array}{c}\text { Estimation of } \\
\text { spatial potential }\end{array}$ \\
\hline
\end{tabular}

The framework assumes to link the three sets of constraints and acquired data in order to build parametric image of designed area within time - the urbanization of an area seen as continuous process in which initial transformation is only keyframe of the evolution of a given estate. Demography helps in establishing community profiling. Planning cannot allow to follow simple hierarchy of participation, which is particularly well put by Bishop and 
Davis [8], and furthermore by Collins and Ison [9, pp. 4-5]. They claim that it is the nature of policy or socially driven solution that determines available and valid forms of participation, and this perspective is relevant to both design and planning.

Social profiling uses multi-scenario analyses followed by simulations done according to seven different approaches, including trend determination, creeping trend polynomial prognosis, triangulated and validated by separately demographic estimation prepared by CBM (Center for Metropolitan Research) [10]. Uncertainty and multiple factors influencing dynamics of demography have been recently proven when governmental social support programs were implemented to stimulate extremely low fertility rate (ca. 1.3 by the end of the first decade of 21 st century). Jointly ten demographic scenarios delivered data for the estimation of functional program for the Rokietnica Center project programming.

In case of programming two alternative methods were used: traditional multifactor based model, and PRS-based time-related extended model. The time-related extended model required the use of pre-programming chart (PPC) and applied according to FAST methodology principles [11]. The easiest task, paradoxically, was related to spatial potential estimation, while it has been measured as a result of selected previous scenario, given in square meters of area and relevant total area. An extended description of the methodological framework is given in Table 2.

Table 2: The overall methodological framework for urban programming.

\begin{tabular}{|c|c|}
\hline \multicolumn{2}{|r|}{ Community profiling } \\
\hline Main & Data collection, inquiries \\
\hline Supplementary & Participatory methods (PRS method) \\
\hline \multicolumn{2}{|r|}{ Tendencies simulation } \\
\hline Main & $\begin{array}{l}\text { Demographic prognoses (various methods - continuation of trend or } \\
\text { naïve method, Browne's method, Holt's method, creeping trend with } \\
\text { harmonic weights method, etc. + authors' method acknowledging } \\
\text { generational amplitude) }\end{array}$ \\
\hline Supplementary & Participatory methods (PRS method) \\
\hline \multicolumn{2}{|r|}{ Estimation of spatial potential + programming } \\
\hline Main & PRS-based time-related extended model \\
\hline Supplementary & $\begin{array}{l}\text { Pre-programming chart (PPC) } \\
\text { Multifactor based mode } \\
\text { Elements of FAST (simulation method) }\end{array}$ \\
\hline
\end{tabular}

\section{VARIOUS CASES: SIMILARITIES AND DIFFERENCES}

The two cases presented in this article refer to two distinct examples of programming and design. The first case depicts programming for central complex, being interwoven into the fabric of suburban community which in recent years became the part of agglomeration of Poznań. Quickly developing center of Rokietnica is an insight into continuous concept of urban design, the extension of existing structure, its counterpoint and culmination, however moderated by the scale, and the capacity of the area located in an empty core of already built-up, surrounding structures. The connections of this center are direct, immediate, and the users of new and existing areas share active urbanized locations - parks, sports center, education facilities, and others. The other case is located in an autonomous location, completely severed from any other urbanized structure. The triangular area in Swarzędz (Ligowiec) is completely detached from other urbanized areas, all three borders defined by railway tracks. Until recently, this area has been used as an airfield, a place to train pilots of 
small airplanes and gliders. Dynamic growth of Swarzędz community justifies variability in development typologies while it is second most intensively developed unit to Poznań within the agglomeration. Its rapid increase in number of inhabitants makes dense, high-rise development a viable option, suitable for a location that is far from any central location, whether related to Poznań or Swarzędz. Thus, two examples are intended to illuminate different concepts of connection between demography and architectural/urban programming - new filling of existing structure being a new local center and autonomous entity, self-sustaining estate.

Few simple formulas have to be introduced to explain connection between demographic prognosis and programming, leaving remaining related formulas as referential [12, p. 43]. First of all, there is a continuous trend of demographic changes, either in the past (real trend) or in the future (prognosis). For particular time frames iterated $\mathrm{P}_{\mathrm{x}}$ states are considered, where $\mathrm{P}$ determines the total number of inhabitants and $\mathrm{x}$ indicates the time span of prognosis (number of years). If this is the case, the change in total number of inhabitants (increase or decrease) affects prognosed number of inhabitants after x number of years (eqn (1))

$$
\mathrm{P}_{\mathrm{x}}=\mathrm{L}+\Delta \mathrm{L}(\mathrm{x}) \text {. }
$$

The density is also considered to expose the spatial parameters of particular community, the efficiency in spatial use. For that purpose, instead of using typical density related to total administrative unit area only urbanized spaces are counted, to determine true densification of built-up areas. The sum of all urbanized areas is necessary for these formulas and is written as $\Sigma \mathrm{T}_{\text {inv }}$ - for simplification sum contains all types of terrains, although these types are counted (and data collected) separately. Users of space are calculated as permanent (inhabitants, permanent residents $-\Lambda_{\text {per }}$ ) and temporary (frequent and occasional users $-\Lambda_{\text {tmp }}$ ) to acknowledge capacity that this way becomes diminished. Therefore, for real spatial density the formula is as follows (eqn (2))

$$
\mathrm{G}_{\mathrm{r}}=\left(\Lambda_{\text {per }}+\Lambda_{\text {tmp }}\right) / \Sigma \mathrm{T}_{\text {inv }} \text { [pers./ha]. }
$$

For future density in $\mathrm{x}$ years, eqn (3) is based on prognosed permanent and temporary users as well as the sum of all housing, services, and infrastructure areas.

$$
\mathrm{G}_{\mathrm{F}(\mathrm{x})}=\left(\mathrm{P}_{\mathrm{per}}(\mathrm{x})+\mathrm{P}_{\mathrm{tmp}}(\mathrm{x})\right) / \Sigma \alpha_{\mathrm{avg}}+\Sigma \alpha_{\mathrm{srv}}+\Sigma \alpha_{\mathrm{inf}}[\text { pers./ha]. }
$$

The optimization of the process of urbanization depends (among other factors) on efficient management of absorptiveness of urbanized areas - how well these areas are used, how well they perform, how harmonious the network of settlements, estates or urban areas are located as a system. Thus, urbanization densification factor is used with acceptable values above 0.75 , and positive values approaching 1.0 - eqn (4). Such a result translates into information, that despite the expansion of urbanized areas the density of population has been maintained and therefore sprawl avoided, because growth is justified and relatively balanced

$$
\Gamma(\mathrm{x})=\mathrm{G}_{\mathrm{F}}(\mathrm{x}) / \mathrm{G}_{\mathrm{r}} .
$$

Respectively mean indicator for urbanization is calculated for existing state and future state, which in turn allows to calculate direct urbanization efficiency indicator (5)

$$
\mathrm{E}=\Psi_{\mathrm{F}} / \Psi_{\mathrm{S}}
$$

To combine this set of factors and indicators used for entire community with particular data derived for limited areas for research purposes pre-programming chart (PPC) was used as a form of unified query to collect other references. The demographic component determines the spectrum of future trends, dynamically altered by several factors (like fertility 
to mortality rate, migration rate, urbanized area dispersion, etc.) and will not be shown here assuming it to be supplementary component of research supporting the main topic of programming. However, the PPC has two other sections - section 2 in a form of binary test of availability of functions ( $0=$ unavailable, $1=$ available $)$, and section 3 in a form of parametric table for accessibility (proximity circles and accessibility estimated time).

In order to illustrate the PPC, above given charts have been filled with data related to Rokietnica case (Table 3).

Table 3: Pre-programming chart, section 3, Rokietnica. (Source: Author, 2016-2019.)

\begin{tabular}{|l|l|c|c|c|c|c|c|c|c|c|c|c|}
\hline \multirow{2}{*}{ Facility type } & $\begin{array}{c}\text { Walking } \\
\text { distance } \\
\text { (m) }\end{array}$ & \multicolumn{2}{|c|}{ Cars/buses (min) } & \multicolumn{3}{|c|}{ Bikes (min) } & \multicolumn{3}{c|}{ Walk (min) } \\
\cline { 2 - 13 } & 500 & 1500 & $\leq 5$ & $\leq 15$ & $>15$ & $\leq 5$ & $\leq 15$ & $>15$ & $\leq 5$ & $\leq 15$ & $>15$ \\
\hline $\begin{array}{l}\text { Administration } \\
\text { facilities }\end{array}$ & & $\mathrm{X}$ & $\mathrm{X}$ & & & & $\mathrm{X}$ & & & $\mathrm{X}$ & \\
\hline $\begin{array}{l}\text { Education } \\
\text { facilities }\end{array}$ & $\mathrm{X}$ & & $\mathrm{X}$ & & & $\mathrm{X}$ & & & $\mathrm{X}$ & & \\
\hline
\end{tabular}

\subsection{Continuous structure}

Rokietnica center is an irregular area that after 1989 was abandoned and since then has not become converted from once agricultural use. The majority of landplots composing this area are private and have limited access to public roads which effectively prevented the development of the area for years. Growth of the community has reached the point in which the center of Rokietnica, despite few drawbacks (like high level of ground water), becomes an irrepressible opportunity to either housing, or apartment, or mixed-use buildings.

This strong influx of people also causes the shift in demographics resulting in making local population younger and increasing the number of children and youth. Two major factors influenced this increase, one being outflow of people from Poznań and inflow of people from outside of metropolitan areas Rokietnica is part of, particularly in recent 10 years, another is national trend stimulated by social programs implemented by the government, aimed at inverting negative demographic trend resulting in fertility as low as lower than 1.3 at the beginning of the 21 st century. Although not its peak, birthrate is quite high and mortality rate relatively low. While in Poland birthrate evolved from 9.19 in 2003 to 10.11 in 2018, and region of Great Poland had these indicators only slightly higher, respectively 9.97 and 11.11 , powiat of Poznan had this number increased from 10.00 to 13.15, and Rokietnica from 9.35 
to 15.08 . Parallelly mortality rate increased from 9.40 to 10.78 in Poland and from 9.10 to 10.06 in Great Poland, but powiat has this number stabilized - 8.04 in 2003 to 7.68 in 2018, while Rokietnica only 6.77 to 7.80 . These relatively positive trends encourage to reassess the total balance to be better than previously predicted, with fertility over 1.5 and growing.

Birth and mortality rates are essential to estimate the development of education facilities (including kindergartens and schools of various levels of education) as well as healthcare facilities (care over minors), sports and recreation areas.

The calculation for the development of the center of Rokietnica settlement has been confronted with overall data related to whole Rokietnica community. These calculations are collected in tables of which the latter is shown below [3]. In this context urbanization of the center may potentially pose problem because of creation of several deficit urban functions required for growing community. While even modest scenarios reveal that the community will sustain further growth efficiently, more probable scenario reveals high urbanization efficiency for the center - typical efficiency for rural areas give results E between 6 and 12 and around 15 to 25 in usual rural centers, is quickly raised to over 50 , as can be seen in Table 4. The density of urbanized areas return average of 10 persons per 1 ha for the community to 165 persons per 1 ha in Rokietnica center ten years ahead.

Table 4: Calculation for Rokietnica center.

\begin{tabular}{|l|c|c|c|c|c|c|c|}
\hline & 2016 & 2018 & 2020 & 2022 & 2024 & 2026 & 2028 \\
\hline Area & 12.07 & 12.07 & 12.07 & 12.07 & 12.07 & 12.07 & 12.07 \\
\hline $\mathrm{L}$ & 154 & 180 & & & & & \\
\hline $\mathrm{P}$ & & & 400 & 800 & 1200 & 1600 & 2000 \\
\hline housing & 0.24 & 0.32 & 4.92 & 4.92 & 4.92 & 4.92 & 4.92 \\
\hline services & 0.01 & 0.02 & 2.01 & 2.01 & 2.01 & 2.01 & 2.01 \\
\hline industry & 0 & 0 & 0.00 & 0.00 & 0.00 & 0.00 & 0.00 \\
\hline total & 0.25 & 0.34 & 6.93 & 6.93 & 6.93 & 6.93 & 6.93 \\
\hline $\mathrm{G}_{\mathrm{r}}$ & 616.00 & 529.41 & & & & & \\
\hline $\mathrm{G}_{\mathrm{F}}$ & & & 57.72 & 115.44 & 173.16 & 230.88 & 288.60 \\
\hline$\Gamma$ & & & 0.11 & 0.22 & 0.33 & 0.44 & 0.55 \\
\hline$\Psi_{\mathrm{S}}$ & 77 & 104.96 & & & & & \\
\hline$\Psi_{\mathrm{F}}$ & & & 1053.00 & 2105.99 & 3158.99 & 4211.98 & 5264.98 \\
\hline $\mathrm{E}$ & & & 10.03 & 20.07 & 30.10 & 40.13 & 50.16 \\
\hline density & 12.76 & 14.91 & 33.14 & 66.28 & 99.42 & 132.56 & 165.70 \\
\hline
\end{tabular}

Continuous structure requires acknowledgment of neighboring districts or areas. It results in obligation to pursue multiple spatial connections - pedestrian connections, bike routes or adapted pathways, individual and public transportation, existing services, which being available diminish probability to be repeated in new developments, particularly, when rare or highly specialized. Programming generator involves weighed parameters which refer to walking distance comfortable accessibility counted as time spent to reach destination and distance in meters. This generator follows demographic dynamics, and also reacts for distinct configurations of customers and/or inhabitants, depending on whether their accessibility is related to walking distance, bike routes reach or private and public transportation systems. Generator allows to input existing facilities and this way to understand what deficits are to be covered by new developments, particularly if these are located centrally (Table 5). 
Table 5: Programming generator for Rokietnica Center.

\begin{tabular}{|l|c|c|c|c|c|c|c|c|c|}
\hline Programming & \multicolumn{7}{|c|}{ Years } & MIN & AVG \\
\cline { 2 - 10 } & 2016 & 2018 & 2020 & 2022 & 2024 & 2026 & 2028 & $\mathrm{~m}^{2}$ & $\mathrm{~m}^{2}$ \\
\hline $\begin{array}{l}\text { Administration } \\
\text { facilities }\end{array}$ & 1440.8 & 1611.3 & 1694.0 & 1862.3 & 2030.6 & 2198.9 & 2367.3 & 257.5 & 643.6 \\
\hline $\begin{array}{l}\text { Education } \\
\text { facilities }\end{array}$ & 1538.3 & 1725.6 & 1954.4 & 2388.9 & 2823.5 & 3258.0 & 3692.5 & 657.3 & 1643.1 \\
\hline $\begin{array}{l}\text { Sports } \\
\text { facilities }\end{array}$ & 3537.7 & 3953.9 & 4086.1 & 4372.4 & 4658.7 & 4945.0 & 5231.3 & 443.1 & 1107.8 \\
\hline $\begin{array}{l}\text { Cultural } \\
\text { facilities }\end{array}$ & 1421.2 & 1588.2 & 1641.5 & 1756.5 & 1871.5 & 1986.5 & 2101.5 & 177.6 & 443.9 \\
\hline $\begin{array}{l}\text { Subsidized/ } \\
\text { other public } \\
\text { services }\end{array}$ & 710.2 & 793.7 & 820.3 & 877.8 & 935.3 & 992.8 & 1050.3 & 88.7 & 221.8 \\
\hline $\begin{array}{l}\text { Religious } \\
\text { facilities }\end{array}$ & 725.5 & 811.6 & 860.3 & 957.8 & 1055.3 & 1152.8 & 1250.3 & 148.7 & 371.8 \\
\hline $\begin{array}{l}\text { Healthcare } \\
\text { facilities }\end{array}$ & 373.0 & 417.8 & 456.8 & 532.2 & 607.7 & 683.1 & 758.5 & 114.4 & 285.9 \\
\hline $\begin{array}{l}\text { Public } \\
\text { transport }\end{array}$ & 710.2 & 793.7 & 820.3 & 877.8 & 935.3 & 992.8 & 1050.3 & 88.7 & 221.8 \\
\hline $\begin{array}{l}\text { Recreation } \\
\text { areas/parks }\end{array}$ & 3087.0 & 3462.7 & 3921.3 & 4791.3 & 5661.2 & 6531.2 & 7401.2 & 1314.9 & 3287.3 \\
\hline $\begin{array}{l}\text { Private } \\
\text { services }\end{array}$ & 3550.8 & 3968.4 & 4101.6 & 4389.1 & 4676.5 & 4964.0 & 5251.5 & 443.6 & 1109.1 \\
\hline
\end{tabular}

The generator has individualized formulas for all pre-programmed functions. These functions are examined under the criteria of availability and accessibility, and also related to growth of population. Accessibility, as explained above, measures time to reach the facility and qualifies particular function, reducing its use by people from outside of the designed area. The main means of transportation - cars, bikes, and walking - are considered and they affect calculations by modifiers. Returned are minimal values, while average values are derived from the former using multiplication by 2.5 .

There are various methods of programming of diverse functions within the city. Factor-based method of calculation of residents' needs is the traditional one and it is based on various indicators [13, p. 25], e.g. in case of commercial services or administration for 1000 residents, in case of schools per students. However, these factors are static, related purely to number of inhabitants, ignoring the availability of space and time-related demographic changes. In Rokietnica case this is particularly important, and it implies the process of simulation and therefore attempt to anticipate possible unfolding of urbanization program. For Rokietnica Center results have been given in the table of recommendations (Table 6).

The above given table proposes minimal required capacities for particular functions. It connects the existing infrastructure with planned development and exposes deficits, changing in time as the estate grows gradually. It allows to plan stages of development and as a result it facilitates decision-making process in which limited resources and financing sources may be allocated more purposefully. 


\begin{tabular}{|c|c|c|c|c|c|c|c|c|c|c|c|}
\hline  &  & $\begin{array}{l}\infty \\
\stackrel{\infty}{*} \\
\stackrel{+}{+}\end{array}$ &  & $x$ & $\begin{array}{l}\overrightarrow{+} \\
\stackrel{n}{0}\end{array}$ & $\stackrel{\circ}{\circ}$ & $\underset{\substack{\infty \\
\infty}}{\stackrel{\infty}{1}}$ & $\begin{array}{l}+\dot{+} \\
\stackrel{\infty}{+}\end{array}$ & $\begin{array}{l}\stackrel{0}{8} \\
\stackrel{\overbrace{}}{\circ}\end{array}$ & $\begin{array}{l}m \\
\infty \\
\infty \\
\cdots \\
\cdots\end{array}$ & $\begin{array}{l}n \\
\dot{n} \\
\frac{\sigma}{1}\end{array}$ \\
\hline 主㐋 &  & $\begin{array}{l}\infty \\
\stackrel{0}{0} \\
m \\
=\end{array}$ & $\begin{array}{l}0 \\
\dot{0} \\
\infty \\
0 \\
\end{array}$ & $x$ & $\begin{array}{l}7 \\
\tilde{n} \\
\tilde{n}\end{array}$ & $\stackrel{\circ}{0}$ & $\begin{array}{l}\infty \\
\stackrel{\infty}{m} \\
=\end{array}$ & $\begin{array}{l}\forall \\
\ddot{n} \\
\ddot{6}\end{array}$ & $\stackrel{\circ}{0}$ & $\begin{array}{l}n \\
\infty \\
\infty \\
0\end{array}$ & $\underset{m}{\tilde{y}}$ \\
\hline  & 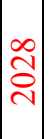 & \begin{tabular}{l}
$n$ \\
\multirow{\sigma}{+}{} \\
$\frac{1}{1}$
\end{tabular} & $\begin{array}{l}n \\
n \\
n \\
n\end{array}$ & $\begin{array}{l}\vec{i} \\
\infty \\
\stackrel{0}{v}\end{array}$ & $\frac{n}{\circ}$ & $\begin{array}{l}n \\
\stackrel{2}{0} \\
\stackrel{2}{1}\end{array}$ & $\begin{array}{l}0 \\
\stackrel{8}{8} \\
\frac{1}{1}\end{array}$ & $\begin{array}{l}n \\
\infty \\
\infty \\
n\end{array}$ & $\begin{array}{l}m \\
0 \\
\infty \\
\infty \\
1\end{array}$ &  & \begin{tabular}{l}
$n$ \\
$\dot{0}$ \\
\hdashline \\
\end{tabular} \\
\hline  & & ஓু & $\stackrel{\infty}{\underset{\sim}{\sim}}$ & ஓ্চ & ஓ̊ & 0 & $\stackrel{8}{\circ}$ & $\stackrel{n}{I}$ & ஓి & ৪ & $\frac{\stackrel{\circ}{7}}{7}$ \\
\hline  &  &  & ڤ్ & $\frac{n}{n}$ & $\frac{n}{\sigma}$ & $\begin{array}{l}n \\
\stackrel{0}{n} \\
\stackrel{0}{0}\end{array}$ &  & $\begin{array}{l}n \\
\infty \\
n \\
n\end{array}$ & $\begin{array}{l}n \\
\stackrel{n}{n} \\
\stackrel{0}{0}\end{array}$ & 旁 & $\begin{array}{l}n \\
\stackrel{n}{n} \\
\text { nn }\end{array}$ \\
\hline  & $\frac{\infty}{\stackrel{\infty}{\sim}}$ & $\stackrel{\circ}{a}$ & $\begin{array}{l}0 \\
\infty \\
m \\
m \\
m\end{array}$ & $\rtimes$ & $\begin{array}{l}0 \\
\dot{n} \\
\infty \\
i \\
i\end{array}$ & $\stackrel{0}{0}$ & $\stackrel{0}{\stackrel{9}{9}}$ & $\begin{array}{l}n \\
\stackrel{n}{n} \\
\end{array}$ & $\stackrel{0}{\stackrel{0}{8}}$ &  & $\begin{array}{l}0 \\
\text { i } \\
\text { O }\end{array}$ \\
\hline 它录 & $\begin{array}{l}\infty \\
\stackrel{\infty}{\curvearrowright} \\
\text { त) }\end{array}$ & $\frac{\circ}{\hat{a}}$ & $\begin{array}{l}\stackrel{0}{0} \\
\stackrel{0}{a} \\
\stackrel{1}{1}\end{array}$ & $x$ & $\begin{array}{l}0 \\
\dot{n} \\
\infty \\
\dot{\gamma}\end{array}$ & $\stackrel{0}{0}$ & $\frac{0}{\hat{a}}$ & $\begin{array}{l}n \\
\infty \\
\infty \\
q\end{array}$ & $\stackrel{0}{0}$ & $\begin{array}{l}n \\
\text { రీ } \\
\text { İ }\end{array}$ & $\begin{array}{l}0 \\
\infty \\
\infty \\
\infty \\
\dot{m}\end{array}$ \\
\hline $\begin{array}{l}: \overrightarrow{0} \\
\stackrel{0}{0} \\
0\end{array}$ & $\frac{\infty}{\stackrel{\infty}{\sim}}$ & $\stackrel{n}{\underset{\pi}{*}}$ & $\frac{\sim}{\sim}$ & $\begin{array}{l}- \\
\dot{0} \\
\dot{+}\end{array}$ & $\begin{array}{l}N \\
\infty \\
\infty \\
= \\
\end{array}$ & $\frac{\hat{\sigma}}{\hat{\sigma}}$ & $\begin{array}{l}\text { n̊. } \\
\stackrel{0}{\circ} \\
0 \\
1\end{array}$ & $\underset{\stackrel{\infty}{+}}{\stackrel{\sim}{\top}}$ & ñ & $\stackrel{n}{n}$ & $\stackrel{0}{\infty}$ \\
\hline  & & ஓ̊ & $\stackrel{\infty}{\stackrel{\infty}{f}}$ & ஓి & \& & 0 & $\stackrel{8}{\circ}$ & $\stackrel{n}{I}$ & ஓి & \& & $\frac{i}{7}$ \\
\hline \multirow[t]{2}{*}{ Z } & $\frac{\infty}{\stackrel{\infty}{\sim}}$ & 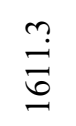 & $\begin{array}{l}6 \\
\stackrel{1}{N} \\
\text { I }\end{array}$ & $\begin{array}{l}\hat{n} \\
\hat{n} \\
\hat{n}\end{array}$ &  & r. & $\begin{array}{l}\text { n̊. } \\
\stackrel{2}{n}\end{array}$ & $\stackrel{\infty}{\stackrel{\infty}{\nabla}}$ & ๙ે &  & $\begin{array}{l}+ \\
\dot{0} \\
0 \\
\stackrel{0}{0} \\
\text { mे }\end{array}$ \\
\hline & &  &  &  &  &  &  &  &  &  &  \\
\hline
\end{tabular}




\subsection{Autonomous structure}

In autonomous case the methodology is much simpler compared to the example described in Rokietnica case, with majority of variables reduced and eliminated from formulas. This is obviously due to the fact, that autonomous structure can be considered without wide environmental/urban context, and that both demographic and spatial aspects of research and calculations are confined to development-related issues. Therefore, data on demographics is less significant, however still important to estimate the number of children and youth. According to data birthrate slowly increased from 2003 being 10.28 then, up to peak value of 14.12 in 2018. Mortality rate at the same time stabilized and almost did not change - in 2003 it was 7.24, and in 2018 it was 7.18. However, in the Swarzędz-Ligowiec (or short Ligowiec) case this balance has less applicability, while it is related to completely new founding, targeted to specific customers and users, who approve bold suburban architectural scheme composed from near zero energy high rise buildings. The isolation of triangular area, separated by the railway tracks and green belts, justifies taking this model as one justifiably liberated from the context.

The investment process takes several years before taking an appropriate shape of autonomous estate, however first year new inhabitants allocate to the area becomes the first referential year for calculating the behavior of the area. At the same time, it is very important for this new urbanized structure to acquire multi-use or diversified areas supplementing residential areas, to ensure that basic services are available and minimal quality of life and comfort sustained. Detached towers located within large publicly accessible park cause efficiency to set value around 40, see Table 7, lower than in the case of Rokietnica Center. Ligowiec has also significantly lower density, 67 persons per 1 ha, however this is related to suppression of spatial potential.

The entire generator chart starts with prognosis, and the first record is the future one. It changes and augments the progress of urbanization, at the same time it allows to detach calculations and restrict them to population of residents of autonomous area only as shown in Table 8 followed with Table 9. It eliminates the necessity to follow the deficit, while there

Table 7: Calculation for Tower Island (estate in Ligowiec).

\begin{tabular}{|l|c|c|c|c|c|}
\hline & 2020 & 2022 & 2024 & 2026 & 2028 \\
\hline Area & 119.06 & 119.06 & 119.06 & 119.06 & 119.06 \\
\hline $\mathrm{L}$ & & & & & \\
\hline $\mathrm{P}$ & 200 & 600 & 1600 & 5000 & 8000 \\
\hline housing & 42.78 & 42.78 & 42.78 & 42.78 & 42.78 \\
\hline services & 17.34 & 17.34 & 17.34 & 17.34 & 17.34 \\
\hline industry & 3.58 & 3.58 & 3.58 & 3.58 & 3.58 \\
\hline total & 63.70 & 63.70 & 63.70 & 63.70 & 63.70 \\
\hline $\mathrm{G}_{\mathrm{r}}$ & & & & & \\
\hline $\mathrm{G}_{\mathrm{F}}$ & 3.14 & 9.42 & 25.12 & 78.49 & 125.59 \\
\hline$\Gamma$ & 1.00 & 3.00 & 8.00 & 25.00 & 40.00 \\
\hline$\Psi_{\mathrm{S}}$ & & & & & \\
\hline$\Psi_{\mathrm{F}}$ & 1596.25 & 4788.74 & 12769.96 & 39906.14 & 63849.82 \\
\hline $\mathrm{E}$ & 1.00 & 3.00 & 8.00 & 25.00 & 40.00 \\
\hline density & 1.68 & 5.04 & 13.44 & 42.00 & 67.19 \\
\hline
\end{tabular}


Table 8: Programming generator for Rokietnica Center.

\begin{tabular}{|l|c|c|c|c|c|c|c|}
\hline \multirow{2}{*}{ Programming } & \multicolumn{5}{|c|}{ Years } & MIN & AVG \\
\cline { 2 - 8 } & 2020 & 2022 & 2024 & 2026 & 2028 & $\mathrm{~m}^{2}$ & $\mathrm{~m}^{2}$ \\
\hline $\begin{array}{l}\text { Administration } \\
\text { facilities }\end{array}$ & 73.3 & 220.0 & 586.7 & 1833.3 & 2933.3 & 366.67 & 916.7 \\
\hline $\begin{array}{l}\text { Education } \\
\text { facilities }\end{array}$ & 206.7 & 620.0 & 1653.3 & 5166.7 & 8266.7 & 1033.33 & 2583.3 \\
\hline $\begin{array}{l}\text { Sports } \\
\text { facilities }\end{array}$ & 106.7 & 320.0 & 853.3 & 2666.7 & 4266.7 & 533.33 & 1333.3 \\
\hline $\begin{array}{l}\text { Cultural } \\
\text { facilities }\end{array}$ & 46.7 & 140.0 & 373.3 & 1166.7 & 1866.7 & 233.33 & 583.3 \\
\hline $\begin{array}{l}\text { Subsidized/ } \\
\text { other public } \\
\text { services }\end{array}$ & 26.7 & 80.0 & 213.3 & 666.7 & 1066.7 & 133.33 & 333.3 \\
\hline $\begin{array}{l}\text { Religious } \\
\text { facilities }\end{array}$ & 46.7 & 140.0 & 373.3 & 1166.7 & 1866.7 & 233.33 & 583.3 \\
\hline $\begin{array}{l}\text { Healthcare } \\
\text { facilities }\end{array}$ & 40.0 & 120.0 & 320.0 & 1000.0 & 1600.0 & 200.00 & 500.0 \\
\hline $\begin{array}{l}\text { Public } \\
\text { transport }\end{array}$ & 26.7 & 80.0 & 213.3 & 666.7 & 1066.7 & 133.33 & 333.3 \\
\hline $\begin{array}{l}\text { Recreation } \\
\text { areas/parks }\end{array}$ & 406.7 & 1220.0 & 3253.3 & 10166.7 & 16266.7 & 2033.33 & 5083.3 \\
\hline $\begin{array}{l}\text { Private } \\
\text { services }\end{array}$ & 106.7 & 320.0 & 853.3 & 2666.7 & 4266.7 & 533.33 & 1333.3 \\
\hline
\end{tabular}

Table 9: Table of recommendations for Ligowiec.

\begin{tabular}{|l|c|c|c|c|c|c|c|c|}
\hline & MIN & Deficit & $\begin{array}{c}\text { IND- } \\
\text { MIN }\end{array}$ & $\begin{array}{c}\text { Deficit } \\
\text { IND }\end{array}$ & Prognosed & Deficit & $\begin{array}{c}\text { IND- } \\
\text { MIN }\end{array}$ & $\begin{array}{c}\text { Deficit } \\
\text { IND }\end{array}$ \\
\hline & 2020 & 2018 & 2018 & 2018 & 2028 & 2028 & 2028 & 2028 \\
\hline $\begin{array}{l}\text { Administration } \\
\text { facilities }\end{array}$ & 73.3 & -73.3 & 20.0 & -20.0 & 2933.3 & -2933.3 & 800.0 & -800.0 \\
\hline $\begin{array}{l}\text { Education } \\
\text { facilities }\end{array}$ & 206.7 & -206.7 & 160.0 & -160.0 & 8266.7 & -8266.7 & 6400.0 & -6400.0 \\
\hline $\begin{array}{l}\text { Sports facilities } \\
\text { indoor }\end{array}$ & 106.7 & -106.7 & $\mathrm{x}$ & $\mathrm{x}$ & 4266.7 & -4266.7 & $\mathrm{x}$ & $\mathrm{x}$ \\
\hline $\begin{array}{l}\text { Cultural } \\
\text { facilities }\end{array}$ & 46.7 & -46.7 & 100.0 & -100.0 & 1866.7 & -1866.7 & 4000.0 & -4000.0 \\
\hline $\begin{array}{l}\text { Subsidized/ } \\
\text { other public } \\
\text { services }\end{array}$ & 26.7 & -26.7 & 0.0 & 0.0 & 1066.7 & -1066.7 & 0.0 & 0.0 \\
\hline $\begin{array}{l}\text { Religious } \\
\text { facilities }\end{array}$ & 46.7 & -46.7 & 20.0 & -20.0 & 1866.7 & -1866.7 & 800.0 & -800.0 \\
\hline $\begin{array}{l}\text { Healthcare } \\
\text { facilities }\end{array}$ & 40.0 & -40.0 & 10.0 & -10.0 & 1600.0 & -1600.0 & 400.0 & -400.0 \\
\hline Public transport & 26. & -26.7 & 0. & 0.0 & 1066.7 & -1066.7 & 0.0 & 0.0 \\
\hline $\begin{array}{l}\text { Recreation } \\
\text { areas/parks }\end{array}$ & 406.7 & -406.7 & 250.0 & -250.0 & 16266.7 & -16266.7 & 10000.0 & -10000.0 \\
\hline Private services & 106.7 & -106.7 & 80.0 & -80.0 & 4266.7 & -4266.7 & 3200.0 & -3200.0 \\
\hline
\end{tabular}


are no existing services to be acknowledged (autonomy of the estate) or such facilities are too far away to affect the social perception and actual quality of use of the area. The deficit values are given in the table for Ligowiec anyway for reference and comparison with Rokietnica case.

The urban network is herein considered as reduced to singular node - the estate itself. This turns the recommendation chart into referential guideline of how to hierarchize the development of services and infrastructure within the estate. Gradual states of built environment hint clues to whether and when particular supplementations to the program become expected, and when absolutely necessary due to appropriate saturation of the environment. What is more, the chart can be easily connected to feasibility studies.

\section{CONCLUDING REMARKS}

The comparison of two cases exhibit similarities and significant differences between Rokietnica Center and Ligowiec. Sustainable development of residential areas cannot be considered without understanding of how interwoven particular area is within the fabric of the community. Even such a simplified approach, in which availability and accessibility features are recognized or simulated for future shape of built environment, exhibit intricate connections between all-community performance and parameters (e.g. demography) and specific shape of individual development, particularly in terms of spatial program.

Both applied methodology and practical recommendations presented and discussed for the two cases display dynamic apparatus, a reactive one, changing instantly with the alteration of design solutions, therefore exploring the opportunities a designer faces. The strategies are obviously different, more decisive actions to be undertaken in an autonomous case, more interconnected space acquired in continual, filling-oriented Rokietnica case. Ligowiec is therefore more seen as more sustainable version of quasi-gated community, open, yet secluded, self-sustaining. For Ligowiec, spatial barriers are becoming advantageous, on the one hand augmenting the autonomy, on the other hand becoming the buffer zone for housing and services allocated to the main zone of the development. Rokietnica is the culmination and the reinforcement of hierarchical relationships. Ligowiec is detached from existing settlement network, however roughly neighbors three of them, giving the opportunity to work with ahierarchical, self-sustaining estate.

\section{REFERENCES}

[1] Graham, S. \& Healey, P., Relational concepts of space and place: Issues for planning theory and practice. European Planning Studies, 7(5), pp. 623-646, 1999.

[2] Barelkowski, R., The edge of the [dis]order. The Sustainable City VII. Urban Regeneration and Sustainability, eds M. Pacetti, G. Passerini, C.A. Brebbia \& G. Latini. WIT Transactions on Ecology and the Environment, vol. 155, WIT Press: Southampton and Boston, pp. 759-770, 2012.

[3] Spiekermann, K. \& Wegener, M., Multi-level urban models: Integration across space, time and policies. The Journal of Transport and Land Use, 11(1), pp. 67-81, 2018.

[4] Madanipour, A., Roles and challenges of urban design. Journal of Urban Design, 11(2), pp. 173-193, 2006.

[5] Barełkowski, R., Strategies for identity of sustainable suburbs. WIT Transactions on Ecology and the Environment, vol. 191, WIT Press: Southampton and Boston, pp. 667-679, 2014.

[6] Carmona, M., The place-shaping continuum: A theory of urban design process. Journal of Urban Design, 19(1), pp. 2-36, 2014. 
[7] Cabrera-Barona, P.F. \& Merschdorf, H., A conceptual urban quality space-place framework: Linking geo-information and quality of life. Urban Science, 2(3), p. 73, 2018.

[8] Bishop, P. \& Davis, G., Mapping public participation in policy choices. Australian Journal of Public Administration, 61(1), pp. 14-29, 2002.

[9] Collins, K. \& Ison, R., Dare we jump off Arnstein's ladder? Social learning as a new policy paradigm. Proceedings of PATH (Participatory Approaches in Science and Technology) Conference, p. 15, 2006.

[10] Kaczmarek, T. \& Bąkowska, E., Prognoza demograficzna gminy Rokietnica dla celów oświatowych 2015-2030. Centrum Badań Metropolitalnych, Uniwersytet im. Adama Mickiewicza w Poznaniu, Poznań, pp. 1-87, 2015.

[11] Barełkowski, R., FAST matrix: Depicting the time-related aspect of urban development. The Sustainable City X. Urban Regeneration and Sustainability, eds C.A. Brebbia \& W.F. Flores-Escobar. WIT Transactions on Ecology and the Environment, vol. 194, WIT Press: Southampton and Boston, pp. 3-10, 2015.

[12] Barelkowski, R. \& Wojtyra, B., Programowanie sanacji przestrzeni wiejskiej. Autorskie mechanizmy planistyczne na rzecz zrownowazonego ksztaltowania obszarow wiejskich. Acta Universitatis Lodziensis, Folia Geographica SocioOeconomica, Społeczny wymiar innowacyjnosci na obszarach wiejskich, 2(32), pp. 31-49, 2018.

[13] Wańkowicz, W., Wskaźniki realizacji usług publicznych, Program Rozwoju Instytucjonalnego, Program Aktywizacji Obszarów Wiejskich (Rural Development Programs), Kraków, ver. 5, pp. 1-70, 2004. 